\title{
Calcium and Ethephon Effects on Paprika Pepper Fruit Retention and Fruit Color Development
}

\author{
James R. Cooksey ${ }^{1}$, Brian A. Kahn ${ }^{2}$ and James E. Motes ${ }^{3}$ \\ Department of Horticulture and Landscape Architecture, Oklahoma State \\ University, Stillwater, OK 74078-0511
}

Additional index words. Capsicum annuum, (2-chloroethyl) phosphoric acid, calcium hydroxide, abscission, mechanical harvest, ripening agent

\begin{abstract}
Ethephon has increased yields of red fruit, but its use as a pepper (Capsicum annuum L.) fruit ripening agent has been limited by premature fruit abscission and defoliation. We tested ethephon solutions of $0,1500,3000,4500$, and $6000 \mu l \cdot l i t e r^{-1}$ with or without $0.1 \mathrm{M} \mathrm{Ca}(\mathrm{OH})_{2}$ as a onetime foliar application to field-grown paprika pepper in southwestern Oklahoma. There was a linear increase in fruit abscission with increasing ethephon rates in 2 of 3 years, with or without added Ca. Marketable fruit as a percentage of total harvested fruit weight was improved by ethephon at $6000 \mu \mathrm{l} \cdot \mathrm{liter}^{-1}$ in 2 of 3 years, primarily due to a decrease in weight of harvested green fruit. However, ethephon never significantly increased the dry weight of harvested marketable fruit over that obtained from the control. There also was no effect of ethephon on the intensity of red pigment extracted from dehydrated marketable fruit. The only consistently significant effect of $\mathrm{Ca}(\mathrm{OH})_{2}$ was an undesirable increase in the retention of green fruit on the plants. Ethephon had little value as a fruit-ripening agent for paprika pepper under the conditions of our studies, and $\mathrm{Ca}(\mathrm{OH})_{2}$ was not useful as an additive to ethephon sprays. Chemical name used: (2-chloroethyl) phosphoric acid (ethephon).
\end{abstract}

Mechanical harvesting of sweet red pepper for processing as paprika is essential to expand production (Bender, 1993; Palevitch, 1978). A prerequisite for mechanical harvesting is the development of cultural practices that facilitate a single destructive harvest (Palevitch, 1978). One such cultural practice is using chemical ripening agents to accelerate (Batal and Granberry, 1982; Worku et al., 1975) and concentrate (Sims et al., 1970) fruit maturity.

Ethephon has effectively concentrated red fruit maturity for a once-over harvest (Cantliffe and Goodwin, 1975) and enhanced red color development in pepper fruit (Knavel and Kemp, 1973) without reducing yield (Sims et al., 1974). Using ethephon also has increased red pigment intensity of fruit (Batal and Granberry,

Received for publication 12 Nov. 1993. Approved for publication by the Director of Oklahoma Agricultural Experiment Station. This research was supported under project $\mathrm{H}-2026$, with additional support from Oklahoma Center for the Advancement of Science and Technology grant ARO-087. We thank Dean Smith, S-S Farms, Hydro, Olda., for his cooperation in the 1992 study. The information given in this publication is for educational purposes only. Mention of a trademark, proprietary product, or vendor does not constitute a guarantee or warranty of the product, nor does it imply approval or disapproval to the exclusion of other products or vendors that may also be suitable. The cost of publishing this paper was defrayed in part by the payment of page charges. Under postal regulations, this paper therefore must be hereby marked advertisement solely to indicate this fact.

'Former Graduate Assistant.

${ }^{2}$ Professor; to whom reprint requests should be addressed.

${ }^{3}$ Professor.
1982; Worku et al., 1975). However, pepper leaf and fruit retention decreased as ethephon rates increased (Batal and Granberry, 1982; Conrad and Sundstrom, 1987). Ethephon applications at rates $>6000 \mu \mathrm{l} \cdot$ liter $^{-1}$ have caused severe fruit abscission on paprika pepper (J.E.M., unpublished data). Conrad and Sundstrom (1987) successfully decreased ethephon-induced abscission in Tabasco pepper (Capsicum frutescens $\mathrm{L}$.) by including 0.1 $\mathrm{M} \mathrm{Ca}(\mathrm{OH})_{2}$ in the ethephon solutions. This treatment has not been investigated for paprika pepper.

Our objective was to compare several rates of ethephon, with and without supplemental foliar $\mathrm{Ca}$ applications as $\mathrm{Ca}(\mathrm{OH})_{2}$, for efficacy in increasing yields of marketable paprika pepper fruit while minimizing premature fruit abscission.

\section{Materials and Methods}

Field experiments were conducted at Fort Cobb Research Station, Fort Cobb, Okla., in 1990 and 1991 and S-S Farms, Hydro, Okla., in 1992. The Cobb fine sandy loam (fine-loamy, mixed, thermic, Udic Haplustalf) at Fort Cobb was prepared with a broadcast, preplant- incorporated application of $40 \mathrm{~N}-45 \mathrm{P}-112 \mathrm{~K}$ $\left(\mathrm{kg} \cdot \mathrm{ha}^{-1}\right)$ in 1990 and $72 \mathrm{~N}-24 \mathrm{P}-46 \mathrm{~K}\left(\mathrm{~kg} \cdot \mathrm{ha}^{-1}\right)$ in 1991, based on soil tests and Oklahoma State Univ. recommendations. The Pond Creek silt loam (fine-silty, mixed, thermic, Pachic Argiustoll) at Hydro was prepared with a broadcast, preplant-incorporated application of $56 \mathrm{~N}$ 12P-46K $\left(\mathrm{kg} \cdot \mathrm{ha}^{-1}\right)$ in 1992. One topdressing each was made in 1990 and in 1991 at first flowering to supply $45 \mathrm{~kg} \mathrm{~N} / \mathrm{ha}$.
Oklahoma Paprika 50, an advanced breeding line with an upright growth habit, was direct-seeded at 2 to $3 \mathrm{~kg} \cdot \mathrm{ha}^{-1}$ with a $0.9-\mathrm{m}$ between-row spacing. Raw seed was planted in plots 11 Apr. 1990, 15 Apr. 1991, and 10 Apr. 1992. Plots were thinned to one plant every $0.1 \mathrm{~m}$ on 27 June 1990 and 18 June 1991. Plots averaged 1.4 plants/0.1 m in 1992 and were not thinned.

At both locations, weeds were controlled with a preplant $N, N$-diethyl-2-(1naphthaleneyloxy)-propionamide (napropamide) application at $1.7 \mathrm{~kg} \cdot \mathrm{ha}^{-1}$ and cultivation. Sprinkler irrigation was provided based on subjective soil observations at Fort Cobb; no irrigation was provided at Hydro.

The experiment design was a split plot, arranged in randomized blocks with three replications in 1990 and 1991. Main plots were ethephon solutions of $0,1500,3000,4500$, or $6000 \mu 1 \cdot$ liter $^{-1}$ sprayed on the pepper plants. Subplots (4 m long) were $\mathrm{Ca}(\mathrm{OH})_{2}$ at 0 or 0.1 $\mathrm{M}$ in the ethephon solutions. Calcium was not used in 1992. The design was a $5 \times 5$ Latin square with the same ethephon rates used previously. Plots were $4 \mathrm{~m}$ long in 1992.

Treatments were applied on 16 Oct. 1990, 19 Oct. 1991, and 9 Oct. 1992, using a CO backpack sprayer calibrated to deliver 74 liters $\cdot \mathrm{ha}^{-1}$. Guard rows were used to minimize the possibility of spray drift between plots. Average temperatures on the dates of application in 1990, 1991, and 1992 were 20, 13, and $16 \mathrm{C}$, respectively. Treatments were timed to occur $\approx 2$ to 3 weeks before the first expected hard frost (at or below -2C). Plants averaged $45 \%$ and $36 \%$ fully colored red fruit at the time of ethephon treatment in 1990 and 1991, respectively. Red fruit also were present at the time of ethephon treatment in 1992, but quantitative data were not taken.

A single destructive harvest was made after a frost in each year to simulate grower practice. Dates of harvest were 19 Nov. 1990, 13 Nov. 1991, and 9 Nov. 1992. Single-row plots were used in 1990 and 1991, and data areas were $2.5 \mathrm{~m}$ long. Double-row plots were used in 1992, so data areas were decreased to $1.5 \mathrm{~m}$ long.

Plants were cut by hand at soil level, counted, and placed in burlap sacks. All fruit on the ground beside the data rows, including those that abscised during harvest, were collected and counted separately. Fruit were removed from the plants in the laboratory. Fruit that were orange, green, bleached, or filled with fungi were classified as culls. Marketable fruit were leathery, partially dried, and deep red (termed "oxblood" in the trade). All plant material was dried at $48 \mathrm{C}$ for $\geq 7$ days and weighed.

Representative samples of marketable fruit with calyxes removed were analyzed for extractable red pigment each year. Dried fruit samples were ground in a Wiley mill to pass through a no. 40 U.S. standard testing sieve $(0.42 \mathrm{~mm})$. Acetone extracts were analyzed for absorbance at $460 \mathrm{~nm}$ using a spectrophotometer (Spectronic 20: Bausch and Lomb, Rochester, N. Y., in 1990 and 1991; Shimadzu UV 160A; Shimadzu, Kyoto, Japan, in 1992) 
according to American Spice Trade Association (ASTA) method 20.0 (ASTA, 1968).

Composite fruit samples also were taken in 1992. Dry fruit weights were obtained from each plot for each classification (oxblood, orange, green, and bleached or fungus-filled) and multiplied by $10 \%$. Fruit (including calyxes) then were taken at random from each classification until the appropriate weight $(10 \%$ of the total for that classification) was reached; fruit pieces were used as necessary. Samples from the four classifications were combined to create a composite sample for each plot. Composite samples were designed to determine whether ethephon treatments were reducing the dilution effect of nonoxblood fruit on ASTA color readings. Composite samples were ground and analyzed as previously described for marketable fruit samples.

We used an analysis of variance to evaluate data and a trend analysis to partition main effects of ethephon rate into linear, quadratic, cubic, and quartic components. A least squares means analysis also was performed in each year to compare individual ethephon rates to the control for possible effects on dry weight of harvested marketable oxblood fruit.

\section{Results and Discussion}

There were no differences in plant stands among the plots in any of the experiments (data not presented). There were no significant $(P \leq 0.05)$ ethephon $\times \mathrm{Ca}$ interactions for any of the measured variables, so only main effects of ethephon and $\mathrm{Ca}$ will be discussed.

Table 1. Response of paprika pepper to ethephon- $\mathrm{Ca}(\mathrm{OH})_{2}$ treatments, Fort Cobb, Okla., 1990. Dry weights are reported. All ethephon $\times \mathrm{Ca}(\mathrm{OH})_{2}$ interactions in this table were not significant at $P \leq 0.05$.

\begin{tabular}{|c|c|c|c|c|c|c|c|c|c|}
\hline \multirow[b]{3}{*}{ Variable } & \multirow{3}{*}{$\begin{array}{c}\text { Avg wt } \\
\text { stems }+ \\
\text { leaves } \\
\text { (g/plant) }\end{array}$} & \multirow{3}{*}{$\begin{array}{c}\text { Total wt } \\
\text { abscised } \\
\text { fruit } \\
\left(\mathrm{g} \cdot \mathrm{m}^{-2}\right)\end{array}$} & \multicolumn{7}{|c|}{ Harvested fruit (abscised excluded) } \\
\hline & & & \multicolumn{5}{|c|}{$\mathrm{Wt} \quad\left(\mathrm{g} \cdot \mathrm{m}^{-2}\right)$} & \multirow{2}{*}{$\begin{array}{l}\% \text { By Wt of } \\
\text { total that was } \\
\text { marketable }\end{array}$} & \multirow{2}{*}{ 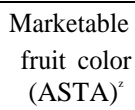 } \\
\hline & & & $\begin{array}{c}\text { Marketable } \\
\text { oxblood }\end{array}$ & Orange & Green & $\begin{array}{l}\text { Bleached or } \\
\text { fungi-filled }\end{array}$ & Total & & \\
\hline \multicolumn{10}{|c|}{ Ethephon $\left(\mu \mathrm{l} \cdot\right.$ liter $\left.^{-1}\right)$} \\
\hline 0 & 8 & 24 & 80 & 5 & 8 & 20 & 114 & 70 & 217 \\
\hline 1500 & 10 & 24 & 104 & 12 & 8 & 20 & 144 & 72 & 219 \\
\hline 3000 & 9 & 27 & 90 & 11 & 6 & 20 & 127 & 70 & 225 \\
\hline 4500 & 8 & 26 & 82 & 8 & 5 & 19 & $113^{-}$ & 72 & 212 \\
\hline 6000 & 8 & 37 & 66 & 7 & 4 & 16 & 93 & 72 & 216 \\
\hline Linear ${ }^{y}$ & NS & $*$ & NS & NS & * & NS & NS & NS & NS \\
\hline \multicolumn{10}{|c|}{$\mathrm{Ca}(\mathrm{OH})_{2}$ at $0.1 \mathrm{M}$} \\
\hline- & 8 & 30 & 80 & 8 & 4 & 18 & 110 & 72 & 212 \\
\hline+ & 9 & 24 & 88 & 9 & 8 & 20 & 126 & 70 & 224 \\
\hline Main effect & NS & NS & NS & NS & $* *$ & NS & NS & NS & NS \\
\hline
\end{tabular}

${ }^{2}$ American Spice Trade Association color units (ASTA, 1968); calyxes removed before analysis.

'Quadratic, cubic, and quartic effects of ethephon were not significant at $P \leq 0.05$.

Ns, Nonsignificant or significant at $P \leq 0.05$ or 0.01 , respectively.

Table 2. Response of paprika pepper to ethephon- $\mathrm{Ca}(\mathrm{OH})_{2}$ treatments, Fort Cobb, Okla., 1991. Dry weights are reported. $\mathrm{All}$ ethephon $\times \mathrm{Ca}(\mathrm{OH})_{2}$ interactions in this table were not significant at $P \leq 0.05$.

\begin{tabular}{|c|c|c|c|c|c|c|c|c|c|}
\hline \multirow[b]{3}{*}{ Variable } & \multirow{3}{*}{$\begin{array}{c}\text { Avg wt } \\
\text { stems }+ \\
\text { leaves } \\
\text { (g/plant) }\end{array}$} & \multirow{3}{*}{$\begin{array}{c}\text { Total wt } \\
\text { abscised } \\
\text { fruit } \\
\left(\mathrm{g} \cdot \mathrm{m}^{-2}\right)\end{array}$} & \multicolumn{7}{|c|}{ Harvested fruit (abscised excluded) } \\
\hline & & & \multicolumn{5}{|c|}{$\mathrm{Wt}\left(\mathrm{g} \cdot \mathrm{m}^{-2}\right)$} & \multirow{2}{*}{$\begin{array}{c}\% \text { By wt of } \\
\text { total that was } \\
\text { marketable }\end{array}$} & \multirow{2}{*}{$\begin{array}{r}\text { Marketable } \\
\text { fruit color } \\
(\text { ASTA })^{2}\end{array}$} \\
\hline & & & $\begin{array}{c}\text { Marketable } \\
\text { oxblood }\end{array}$ & Orange & Green & $\begin{array}{l}\text { Bleached or } \\
\text { fungi-filled }\end{array}$ & Total & & \\
\hline \multicolumn{10}{|c|}{ Ethephon $\left(\mu l \cdot\right.$ liter $\left.^{-1}\right)$} \\
\hline 0 & 10 & 22 & 23 & 7 & 28 & 5 & 63 & 36 & 198 \\
\hline 1500 & 11 & 20 & 25 & 9 & 30 & 8 & 71 & 34 & 198 \\
\hline 3000 & 9 & 18 & 22 & 9 & 29 & 4 & 64 & 34 & 193 \\
\hline 4500 & 9 & 20 & 19 & 9 & 26 & 4 & 58 & 32 & 191 \\
\hline 6000 & 9 & 20 & 27 & 8 & 24 & 5 & 64 & 41 & 190 \\
\hline Response $^{y}$ & NS & NS & Ns & NS & NS & $\mathrm{C}^{*}$ & NS & $\mathrm{Q}^{* *}$ & NS \\
\hline \multicolumn{10}{|c|}{$\mathrm{Ca}(\mathrm{OH})_{2}$ at $0.1 \mathrm{M}$} \\
\hline - & 9 & 20 & 22 & 8 & 24 & 5 & 58 & 37 & 194 \\
\hline+ & 10 & 20 & 25 & 9 & 31 & 6 & 70 & 34 & 195 \\
\hline Main effect & $* *$ & NS & NS & NS & $* *$ & NS & $*$ & NS & NS \\
\hline
\end{tabular}

${ }^{2}$ American Spice Trade Association color units (ASTA, 1968); calyxes removed before analysis.

'Linear, quadratic $(\mathrm{Q})$, cubic $(\mathrm{C})$, and quartic effects of ethephon were tested.

${ }_{\text {N. }, \text { s, }}$ Nonsignificant or significant at $P \leq 0.05$ or 0.01 , respectively.

Table 3. Response of paprika pepper to ethephon treatments, Hydro, Okla., 1992. Dry weights are reported.

\begin{tabular}{|c|c|c|c|c|c|c|c|c|c|c|}
\hline \multirow[b]{3}{*}{ Variable } & \multirow{3}{*}{$\begin{array}{c}\text { Avg wt } \\
\text { stems + leaves } \\
\text { (g/plant) }\end{array}$} & \multirow{3}{*}{$\begin{array}{l}\text { Total wt } \\
\text { abscised } \\
\text { fruit } \\
\left(\mathrm{g} \cdot \mathrm{m}^{-2}\right)\end{array}$} & \multicolumn{8}{|c|}{ Harvested fruit (abscised excluded) } \\
\hline & & & \multicolumn{5}{|c|}{$\mathrm{Wt}\left(\mathrm{g} \cdot \mathrm{m}^{-2}\right)$} & \multirow{2}{*}{$\begin{array}{l}\% \text { By wt of } \\
\text { total that was } \\
\text { marketable }\end{array}$} & \multicolumn{2}{|c|}{ Fruit color } \\
\hline & & & $\begin{array}{c}\text { Marketable } \\
\text { oxblood }\end{array}$ & Orange & Green & $\begin{array}{l}\text { Bleached or } \\
\text { fungi-filled }\end{array}$ & Total & & $\begin{array}{l}\text { Composite }^{z} \\
\text { (ASTA) }\end{array}$ & $\begin{array}{c}\text { Marketable } \\
\text { (ASTA) }\end{array}$ \\
\hline \multicolumn{11}{|c|}{ Ethephon $\left(\mu 1 \cdot\right.$ liter $\left.^{-1}\right)$} \\
\hline 0 & 29 & 56 & 259 & 21 & 77 & 3 & 360 & 71 & 98 & 181 \\
\hline 1500 & 30 & 72 & 277 & 19 & 43 & 4 & 342 & 80 & 107 & 183 \\
\hline 3000 & 34 & 72 & 229 & 21 & 52 & 3 & 305 & 75 & 109 & 182 \\
\hline 4500 & 27 & 105 & 204 & 22 & 43 & 2 & 270 & 75 & 106 & 197 \\
\hline 6000 & 24 & 108 & 225 & 16 & 27 & 2 & 270 & 83 & 107 & 187 \\
\hline Response $^{\mathrm{x}}$ & NS & $\mathrm{L}^{* *}$ & $\mathrm{C}^{*}$ & NS & $\mathrm{C}^{* *}$ & NS & $\mathrm{L}^{* *}$ & $\mathrm{C}^{* *}$ & NS & NS \\
\hline
\end{tabular}

Composite samples consisted of $10 \%$ (by weight) random fruits from each of the four fruit categories, including calyxes, from each plot (see text for details). Calyxes were removed for the separate analysis of marketable fruit.

'American Spice Trade Association color units (ASTA, 1968).

${ }^{x}$ Linear (L), quadratic, cubic (C), and quartic effects of ethephon were tested.

${ }_{\text {Ns. }, *=}$ Nonsignificant or significant at $P \leq 0.05$ or 0.01 , respectively. 
Stem and leaf dry weights per plant showed no significant effect of ethephon treatment (Tables 1-3). The addition of $\mathrm{Ca}$ as $0.1 \mathrm{~m}$ $\mathrm{Ca}(\mathrm{OH})_{2}$ increased the mean stem and leaf dry weight by $1 \mathrm{~g} /$ plant in 1990 and 1991, but the increase was significant only in 1991 (Tables 1 and 2). The increase was due to better leaf retention with additional $\mathrm{Ca}$, as reported by Conrad and Sundstrom (1987). However, leaf retention after frost is not desirable, as the leaves would constitute trash in mechanically harvested fruit.

The total "dry weight of abscised fruit increased linearly as the ethephon rate increased in 1990 and 1992 (Tables 1 and 3). Others have reported similar responses (Batal and Granberry, 1982; Cantliffe and Goodwin, 1975; Conrad and Sundstrom, 1987). Calcium had no significant effect on the total weight of abscised fruit in 1990 or 1991 (Tables 1 and 2). Conrad and Sundstrom (1987) reported that fruit retention percentages were higher for Tabasco pepper when ethephon was applied with $0.1 \mathrm{M} \mathrm{Ca}(\mathrm{OH})_{2}$ than when $\mathrm{Ca}$ was not included.

The dry weight of harvested marketable oxblood fruit showed a response to ethephon only in 1992, when a cubic decrease was noted (Tables 1-3). Results of the least squares means analyses (not presented) confirmed that none of the ethephon treatments gave a significant increase in the dry weight of harvested marketable oxblood fruit compared to the control in any year. Ethephon has increased the yield of red peppers in other studies (Batal and Granberry, 1982; Cantliffe and Goodwin, 1975). Calcium had no significant effect on the dry weight of harvested marketable oxblood fruit (Tables 1 and 2). Neither ethephon nor $\mathrm{Ca}$ affected the dry weight of harvested orange fruit (Tables 1-3). The dry weight of harvested green fruit decreased linearly in 1990 and cubically in 1992 in response to increasing ethephon rates (Tables 1 and 3). Calcium, however, increased the weight of harvested green fruit in 1990 and 1991 (Tables 1 and 2). There were few treatment effects on the dry weight of harvested fruit that were bleached or fungus-filled (Tables 1-3).

Ethephon treatments decreased the total dry weight of harvested fruit only in 1992 (Tables 1-3). Cantliffe and Goodwin (1975) obtained decreased pepper fruit yields with a single $500 \mu \mathrm{l}$ ethephon spray/liter, as did Batal and Granberry (1982) with two 500- $\mu$-liter sprays. However, plants in both of these earlier studies were sprayed until runoff. Calcium tended to increase the total dry weight of harvested fruit in 1990 and 1991, but the response was significant only in 1991 (Tables 1 and 2).

Harvested fruit yields varied among years (Tables 1-3). Marketable fruit yields in particular were reduced by hail at Fort Cobb in 1991. Many of the hail-damaged plants set a late fruit crop, but most of these fruit were too immature at the time of ethephon application to be effectively ripened (Lockwood and Vines, 1972). Yields were high at Hydro in 1992, because of a combination of unusually favorable weather, a high plant population, and a site that had not been used previously for vegetable production.

Marketable fruit, as a percentage of total harvested fruit weight, increased quadratically and cubically with increasing ethephon rates in 1991 and 1992, respectively, with no response in 1990 and no response from the $\mathrm{Ca}$ addition in 1990 or 1991 (Tables 1-3). The significant responses were due primarily to decreases in the dry weight of harvested green fruit with ethephon rates of $6000 \mu \mathrm{l} \cdot$ liter $^{-1}$, especially in 1992. Others also have reported increases in marketable (red) fruit as a percentage of total fruit yield following ethephon treatments (Batal and Granberry, 1982; Cantliffe and Goodwin, 1975; Sims et al., 1970).

Worku et al. (1975) and Batal and Cranberry (1982) reported that ethephon increased the red pigment intensity of marketable fruit, but we found no effect on color with ethephon or Cain our studies (Tables 1-3). Even in 1992, when ethephon treatments decreased green fruit yield and increased marketable fruit as a percentage of total harvested fruit weight, the intensity of red pigment extracted from composite fruit samples was improved by an average of less than 10 ASTA units with ethephon treatments, and this response was not significant (Table 3). This finding indicates that ethephon treatment cannot substitute for color sorting of composite fruit yields before shipping to the processor.

Ethephon treatments never significantly increased the dry weight of harvested market- able fruit over that obtained from the control in our studies. There also was no effect of ethephon on the intensity of red pigment extracted from dehydrated marketable fruit. The addition of $\mathrm{Ca}$ as $0.1 \mathrm{M} \mathrm{Ca}(\mathrm{OH})_{2}$ to ethephon solutions did increase the total harvested fruit yield in 1991, but this increase was in nonmarketable fruit (Table 2). Thus, ethephon had little value as a fruit-ripening agent for paprika pepper under the conditions of our studies. Furthermore, $\mathrm{Ca}(\mathrm{OH})_{2}$ was not useful as an additive to ethephon sprays.

\section{Literature Cited}

American Spice Trade Association. 1968. Official analytical methods of the American Spice Trade Association. 2nd ed. Amer. Spice Trade Assn., Englewood Cliffs, N.J.

Batal, K.M. and D.M. Granberry. 1982. Effects of growth regulators on ripening and abscission of pimiento and paprika peppers. HortScience 17:944-946.

Bender, D.A. 1993. Pepper production and harvesting research for the High Plains. In: B. Villalon (cd.). Proc. Ninth Biennial Texas Pepper Conf., Weslaco, Texas.

Cantliffe, D.J. and P. Goodwin. 1975. Red color enhancement of pepper fruits by multiple applications of ethephon. J. Amer. Soc. Hort. Sci. 100:157-161.

Conrad, R.S. and F.J. Sundstrom. 1987. Calcium and ethephon effects on Tabasco pepper leaf and fruit retention and fruit color development. J. Amer. Soc. Hort. Sci. 112:424-426.

Knavel, D.E. and T.R. Kemp. 1973. Ethephon and CPTA on color development in bell pepper fruits. HortScience 8:403-404.

Lockwood, D. and H.M. Vines. 1972. Red color enhancement of pimiento peppers with (2-chloroethyl)phosphonic acid. J. Amer. Soc. Hort. Sci. 97:192-196.

Palevitch, D. 1978. Cultural practices and cultivars for once-over harvested sweet paprika. Acts Hort. 73:255-262.

Sims, W.L., H.B. Collins, and B.L. Gledhill. 1970. Ethrel effects on fruit ripening of peppers. Calif. Agr. 24(2):45.

Sims, W.L., D. Ririe, R.A. Brendler, M.J. Snyder, D.N. Wright, Y.H. Schweers, and P.P. Osterli. 1974. Factors affecting ethephon as an aid in fruit ripening of peppers. CaliforniaAgr. 28(6):3-4.

Worku, Z., R.C. Herner, and R.L. Carolus. 1975. Effect of stage of ripening and ethephon treatment on color content of paprika pepper. Scientia Hort. 3:239-245. 